\title{
如何加强林业经济管理促进林业和谐发展
}

\author{
刘震萍 \\ 黑龙江省八五七农场林业科
}

DOI:10.32629/ej.v2i6.322

[摘 要] 在现阶段的国内经济发展当中,林业是基础的产业之一,其本身对人类的生产生活有着相当重要的意义,而这种意义不仅仅表现在基础 的经济效益上, 而且对保持自然生态环境的和谐有着一定的促进作用。因而需要相关人员切实加强对林业的科学管理, 实时解决林业发展过程中 遇到的各种危险,并加强对林业的整体经济管理,促使林业可以健康和谐地发展起来。

[关键词] 林业; 经济管理; 可持续发展

\section{1 目前林业经济管理存在的问题}

1. 1 森林资源过度开发

与国外的先进国家相比, 我国在林业经济管理中还存在着一定的问题, 严重制约着林业经济以及产业化的发展, 具有一定的阻碍作用, 森林资源 的过度开发是其中较为严重的问题之一。随着科学技术的发展, 我国的工 业化水平日益提高, 城市化发展迅速, 对各种资源的需求急剧增加, 包括对 树木的需求, 过度开发森林资源, 使得森林面积迅速减小, 从而使森林资源 保护形势日趋严峻。

1.2林业产业化低

林业化产业低也是我国农业管理面临的重要问题。现阶段, 我国农林 的经营方式为分散式, 缺乏有效的经营机制, 机制的缺失阻碍了林业向着 市场化发展的步伐, 一方面不利于林业产业化的深化, 另一方面也给林业 经济发展带来了负面影响。林业产业化低会导致林业发展失衡, 致使林业 不同区域的发展水平存在差别。在经济发展比较快速的地区, 林业产业化 已初具规模, 形成了产业链及规模, 而有些林业资源丰富的地区由于管理 水平低下, 无法与市场接轨, 从而为林业的总体发展造成一定的障碍。

\section{3 林业资源相对不足}

在长期的发展过程中, 因为受到自身市场经济特点的影响, 导致我国的 林业资源始终存在着质量下滑与总量不足的问题。再加上我国是一个人口 众多的国家, 进一步降低了林业资源的人均储蓄量。此外, 由于对人们的过 度采伐, 导致整个林业的木材比例始终在下降, 也正因如此, 导致其在对林 业资源的有效利用时, 难以获得一个切实的保障。我国的相关法律对于林业 开采进行了明确的规定, 要求其必须要将开采量控制在某一范围内, 若对其 进行过度的开采, 其不仅很难保障林业的自然效力, 同时也将会严重影响到 林业的自我恢复能力。现阶段, 我国正处于新时代的社会建设时期, 随着城 市化与工业化的不断深入, 其对于林业资源也提出了更高的开发需要, 再加 上城市化的发展, 占据了一定的林业面积, 加重了林业资源不足的问题。

\section{2 加强林业经济管理促进林业和谐发展的措施}

2.1优化林业产业结构和生产模式

林业的产业结构对于经济管理有着重要的意义, 加快林业产业结构升 级对于提高经济效益与林业发展水平有着巨大的作用。产业结构的完善和 升级能够促进现今的林业资源优势慢慢向科技优势方向发展。借助相关政 策的优惠以及经济方面的促进作用, 积极推动林业经济往森林经济方向发 展。目前我国林业发展呈现一种不均衡的状态, 产业结构也呈现出多种不 同的形态, 因此, 在保障发展结构优化的同时不断的改善其经济的发展方 向。在保障林业生产循环的基础上, 致力于创建节约型生产模式, 科学的使
用林业生产的土地, 科学的利用相关资源, 对林业生产的相关资源进行合 理的配置, 优化资源配置和产业结构。致力于走上林业产业科学合理、生 态节约的和谐发展方向, 促进林业的和谐发展。

\section{2创新林业制度管理}

对林业产业加强制度管理, 不仅保障了林业产业的正常运行, 而且推 动了林业产业的经济发展。对林业制度管理进行创新有以下方面: 一是规 范林木采伐管理。对林木的砍伐制度进行规范管理, 并采取监督制度, 实施 责任制, 从而减少乱砍滥伐的现象发生。二是规范林木检疫管理。严格按 照林木检疫管理制度对林木进行检疫工作, 防止病虫害的传播, 使林木得 到有效的保护。三是规范林地管理。应加强对林地的使用管理, 防止恶意 占领林地的现象发生。四是规范木材加工厂管理。对木材加工厂进行管理, 其目的在于有效的保护和合理使用林木。

2.3 促进生态产业的进一步发展

随着人类对资源的需求和掠夺不断加剧, 我国当今林业发展迎来了较 多的挑战。从现实情况出发, 目前光靠市场还是难以协调资源与人口增长 之间的矛盾。即便是在国家政策的管理控制下, 我国的人口基数还是呈不 断增长的状态, 但是自然资源的总量是有限的, 即便我国地大物博, 但人均 资源占有率还是十分的少, 对资源的利用过程中还会对生态环境造成较大 的影响。针对这些现状, 要求我们加强对生态产业的建设。一是可以加强 “用绿”, “向林地要产出、向空间要效益”, 充分利用好森林资源发展林 下经济, 发展林业产业, 既保护了生态资源, 又促进了林农增收致富。二是 结合林权改革 “活绿”, 美化生态兴林富民。深化集体林权制度改革, 探索 推行林地经营权流转制度, 激发改革活力, 使生态得到保护, 林业增效益, 百姓得实惠。

\section{3 结语}

当前我国社会经济发展较快, 其中林业问题较为突出, 对林业经济管 理工作进行创新, 提高林业经济管理效率对促进社会发展、生态环境保护 等方面具有重要意义。当前相关部门需要完善各项管理制度, 强化监督管 理工作, 更好地促进林业经济发展。

\section{[参考文献]}

[1]张海龙,于洪军.浅议新经济形势下林业经济创新的管理和发展 [J]. 山西农经,2019(07):108.

[2]王英.简析新经济形势下林业经济创新管理和发展前景[J].现代经 济信息,2018(22):363.

[3]间超,蔡恒明,赵眉芳.林业经济可持续发展建议[J].现代农业科 技,2019(7):138. 